Animal Production and Environment Received on: 07/04/2020

Accepted on: 13/10/2020

\title{
Effectiveness of flor-de-seda and pomegranate aqueous extracts on eggs of the Heterakoidea Superfamily isolated from naturally infected japanese quails
}

\section{Eficácia dos extratos aquosos de Flor de Seda e Romã sobre ovos da Superfamília Heterakoidea isolados de codornas japonesas}

BRANDÃO, Patrícia Araujo ${ }^{1}$

https://orcid.org/0000-0002-7223-2025

SILVA, David Rwbystanne Pereira da ${ }^{2 *}$ https://orcid.org/0000-0002-9804-0355
DINIZ, Giuliana Garcia ${ }^{1}$

https://orcid.org/0000-0001-5734-4216

VILELA, Vinícius Longo Ribeiro ${ }^{3}$

https://orcid.org/0000-0001-9891-7842

${ }^{1}$ Federal University of Campina Grande, Rural Health and Technology Center, Academic Unit of Veterinary Medicine, Patos, Paraíba, Brazil.

${ }^{2}$ Federal University of Paraíba, Center of Agrarian Sciences, Integrated Doctoral Program in Animal Science UFPB/UFC/UFRPE, Areia, Paraíba, Brazil.

${ }^{3}$ Federal Institute of Paraíba, Department of Veterinary Medicine, Sousa, Paraíba, Brazil.

*Corresponding author: davidrwbystanne@hotmail.com

\begin{abstract}
The present study aimed to evaluate the in vitro anthelmintic efficacy of flor-de-seda (Calotropis procera S.W.) and pomegranate (Punica granatum L.) extracts on gastrointestinal nematode eggs of Japanese quails. Stool samples were collected from a herd of 5,000 adult birds raised on the floor at a commercial farm in the state of Ceará, Brazil. The samples were packed in plastic bags, kept refrigerated and transported for laboratory analysis. The eggs were placed in $2.5 \mathrm{ml}$ of the suspension and $2.5 \mathrm{ml}$ of florde-seda and pomegranate extracts in concentrations of $50 ; 25 ; 12.5 ; 6.25$ and $3.12 \%$. Readings were subsequently taken at 24,48 and 72 hours. The aqueous pomegranate extract at 25 and $50 \%$ was more efficient on the larvae hatching. The flor-de-seda aqueous extract in both concentrations and evaluation periods showed similar action to that of the positive control treatment (Albendazole 10\%). The pomegranate and flor-deseda aqueous extracts have anthelmintic activity on the development of larvae in eggs of the Heterakoidea Superfamily and are therefore presented as an alternative to replace the drugs commonly used to control helminths in Japanese quails.
\end{abstract}

Keywords: birds, gastrointestinal parasites, medicinal plants

\section{RESUMO}

O presente estudo teve por objetivo avaliar a eficácia anti-helmíntica "in vitro" dos extratos de flor de seda (Calatropis procera $S$. W.) e de romã (Punica Granatum L.) 
sobre ovos de nematoides gastrintestinais de codornas japonesas. Foram colhidas amostras de fezes em um plantel de cinco mil aves adultas, criadas sobre o piso em uma granja comercial no estado do Ceará, Brasil. As amostras foram acondicionadas em sacos plásticos, mantidas refrigeradas e transportadas ao Laboratório de Doenças Parasitárias dos Animais Domésticos (LDPAD) do Centro de Saúde e Tecnologia Rural da UFCG. Os ovos foram colocados em $2,5 \mathrm{ml}$ da suspensão e 2,5 $\mathrm{ml}$ dos extratos de flor de seda e romã, nas concentrações de $50 ; 25 ; 12,5 ; 6,25$ e 3,12\%. As leituras foram realizadas em 24, 48 e 72 horas. O extrato aquoso de romã a 25 e $50 \%$ apresentou uma melhor ação sobre a eclosão de larvas. Já o extrato aquoso de flor de seda em ambas as concentrações e períodos de avaliação apresentou ação semelhante a do tratamento controle positivo (Albendazole 10\%). Os extratos aquosos de romã e flor de seda apresentam atividade anti-helmíntica sobre a eclosão de larvas de Ascaridia sp. e se apresentam como uma alternativa para substituição dos fármacos comumente utilizados no controle de helmintos em codornas japonesas.

Palavras-chave: aves, parasitoses gastrointestinais, plantas medicinais

\section{INTRODUCTION}

Quail farming is an activity which requires little space, low initial investment, has a short-term financial return and has shown a marked growth in the animal production scenario in recent years (Silva et al. 2018). Factors such as an increase in the consumption of eggs and quail meat by the population have led to an increase in this production sector.

Intestinal parasitosis is considered as one of the serious health problems in poultry, especially those raised on the floor, causing great economic losses due to growth retardation, reduced production rates such as egg production and increased susceptibility to diseases (Vitta et al. 2014).

Prophylactic treatment with synthetic anthelmintics is the first control measure in production systems. The incidence of anthelmintic resistance has sporadically been reported in certain populations of helminths. In the absence of highly effective drugs, the use of other less conventional methods can provide a solution to the problem (Tariq
\& Tantry, 2012; Vita et al. 2015). In addition, organic production, the growing concern with food security and the reduction of production costs justify the use of plants with proven antiparasitic action as an alternative to commonly used antiparasitic drugs.

The main gastrointestinal nematodes which affect birds raised on the floor are Ascaridia galli and Heterakis gallinarum due to direct contact with excreta, causing granulomas in the intestine, obstruction and death of animals (Abdelqader et al. 2012; Ruff, 1999).

Pomegranate is used in traditional medicine as an antimicrobial, antiinflammatory and natural antioxidant with proven action on a wide class of bacteria and parasites, as it has polyphenols and tannins in its skin which make it impossible for helminths and microorganisms to develop (Dkhil, 2013; Abdel Monein, 2012). The florde-seda also has a proven action and 80 to $100 \%$ effectiveness in treating intestinal parasites in small ruminants (Cavalcante et al. 2016; Nery et al. 2009), however studies on the 
evaluation of these plants in quails are still scarce.

Therefore, this study aimed to evaluate the anthelmintic activity of aqueous extracts from the flowers and fruit of flor-de-seda (Calotropis procera) and pomegranate skin (Punica granatum) on eggs of the Heterakoidea Superfamily isolated from naturally infected Japanese quails.

\section{MATERIAL AND METHODS}

The plants $(C$. procera and $P$. granatum) used were collected in the city of Patos, located in the Paraíba mesoregion, Brazil $\left(07^{\circ} 01^{\prime} 28^{\prime}\right.$ ' $\mathrm{S} / 37^{\circ}$ 16 ' 48' W). P. granatum peels (pomegranate) and the flowers and fruit of $C$. procera (flor-de-seda) were used to obtain the aqueous extracts.

The pomegranate and flor-de-seda samples were subjected to laboratory hygiene procedures under running water after collection and were placed in air drying for 48 hours, then taken to the forced ventilation oven at $60^{\circ} \mathrm{C}$ for 24 hours. They were soon after weighed and ground in an industrial mill, according to the methodology described by Araújo et al. (2011).

Next, they were placed in sterilized glass containers to prepare the extracts using pomegranate and flor-de-seda bran separately in the proportion of $250 \mathrm{~g}$ of plant material to $100 \mathrm{~g}$ of distilled water, remaining submerged for a period of 24 hours. After this period they were filtered using filter paper. The filtered liquid (initial volume = v1) was transferred in small portions $(100 \mathrm{ml})$ to amber containers, adding distilled water to obtain the desired concentrations (final volume $=\mathrm{v} 2$ ), and kept under refrigeration until the moment of carrying out the tests.

The animals' feces for in vitro tests were collected in the city of Lavras da Mangabeira, in the state of Ceará, Brazil, from a single Japanese quail (Coturnix coturnix japonica) breeding stock intended for commercial laying composed of five thousand adult birds raised on the floor with beaten sugarcane bagasse, all of them being of productive age. The excreta were collected using cardboard sheets placed on the bed in the morning and removed in the late afternoon, after which possible impurities were removed which would have adhered to the collected material and were later stored in plastic bags, refrigerated and immediately sent to the Laboratory of Parasitic Diseases of Domestic Animals (LDPAD) of the Federal University of Campina Grande, Campus de Patos-PB.

Parasite eggs were obtained using the technique by Girão \& Ueno (1985). The material was crushed in a grail containing hypersaturated saline, then filtered through mesh sizes of 250 $\mathrm{nm} / \mathrm{nm}$ (No. 60) and $180 \mathrm{~nm} / \mathrm{nm}$ (No. $80)$. The obtained material was placed in $500 \mathrm{ml}$ beakers and then three consecutive washes were carried out with distilled water. In the last wash, the sediment was maintained with a small volume of distilled water in order to compose a suspension with approximately 100 eggs $/ \mathrm{ml}$, followed by that applied by Hubert \& Kerboeurf (1984). Petri dishes $10 \mathrm{~cm}$ in diameter were used with $2.5 \mathrm{ml}$ of aqueous extract of pomegranate and flor-de-seda in concentrations of $50 ; 25 ; 12.5 ; 6.25$; and $3.12 \% \mathrm{mg} / \mathrm{ml}^{-1}$ for every 250 eggs, meaning $2.5 \mathrm{ml}$ of the filtrate. The test was carried out in triplicates. Next, 2.5 
$\mathrm{ml}$ containing 250 eggs and $2.5 \mathrm{ml}$ of distilled water were used for the negative control. The positive control was performed with Albendazole $10 \%$. The addition of extracts to the plates with recently collected eggs enabled evaluating their effect on the larvae development by the "in vitro" test, as performed by Coles et al. (1992). The plant extract action was evaluated during the incubation period of 24,48 and 72 hours. The procedure was also repeated with the positive and negative controls. The readings were performed in optical microscopes at 100 times magnification. All the eggs present in the samples were evaluated, classifying them as viable and non-viable, and they were identified and counted in the petri dishes.

A completely randomized design with factorial arrangement $(2 \times 5+2)$ was used, and two plant extracts both with five concentrations $(50 ; 25 ; 12.5 ; 6.25$ and $3.12 \%$ of pomegranate and flor-de-seda extract), plus the positive and negative group, according to the methodology described by Hubert \& Kerboeurf (1984).
The dilutions within each group (plant extract) were compared by analysis of variance (ANOVA) in a classification criterion, with multiple comparisons by the Tukey test. The comparison of several dilutions two by two between the different extracts was performed using the Student's t-test (Zar, 1999). The significance level adopted was 5\% and the analyzes were performed using the MINITAB version 14.0 statistical program.

\section{RESULTS AND DISCUSSION}

The helminth eggs found in the study belong to the Ascaridia and Heterakis genera, belonging to the Heterakoidea Superfamily and the Cyclophyllidea order. Similar results were verified by Feitosa et al. (2013), Carneiro et al. (2011) and Sabri (2013) when searching for parasites in poultry feces.

The pomegranate aqueous extract activity calculated through the inhibition rate on the development of Ascaridia spp. and Heterakis spp. are shown in Table 1.

Table 1. Averages of the results of the activity of aqueous pomegranate extract calculated through the rate of inhibition of larvae development in eggs of the Heterakoidea Superfamily in different concentrations

\begin{tabular}{ccccc}
\hline \multirow{2}{*}{ Treatment } & & \multicolumn{3}{c}{ Larval Development Inibition (\%) } \\
\cline { 3 - 5 } & $\begin{array}{c}\text { Concentrations } \\
(\%)\end{array}$ & 24 hours & 48 hours & 72 hours \\
& 03.12 & $16.0 \mathrm{~b}$ & $16.0 \mathrm{~b}$ & $19.0 \mathrm{~b}$ \\
Pomegranate & 06.25 & $22.0 \mathrm{~b}$ & $15.0 \mathrm{~b}$ & $20.0 \mathrm{~b}$ \\
& 12.50 & $30.0 \mathrm{~b}$ & $24.0 \mathrm{~b}$ & $33.5 \mathrm{~b}$ \\
& 25.00 & $63.0 \mathrm{a}$ & $77.5 \mathrm{a}$ & $78.0 \mathrm{a}$ \\
No treatment $*$ & 50.00 & $70.0 \mathrm{a}$ & $73.8 \mathrm{a}$ & $77.0 \mathrm{a}$ \\
Albendazole $* *$ & - & $05.0 \mathrm{~b}$ & $12.0 \mathrm{~b}$ & $07.0 \mathrm{~b}$ \\
& 10 & $20.0 \mathrm{~b}$ & $15.0 \mathrm{~b}$ & $21.0 \mathrm{~b}$ \\
\hline
\end{tabular}




\author{
* Negative control (-) \\ ** Positive control $(+)$ \\ Means followed in different letters by the Tukey test $(p<0,05)$
}

Pomegranate extracts at concentrations of 25 and $50 \%$ showed the highest rates of hatch inhibition at each incubation time evaluated, and did not differ significantly between them. Similar results were verified by Fernandes et al. (2009) when working with ethanolic sugar-apple (Annona squamosa) extract in treating $A$. galli in poultry and observed similar effects to those found in this study, where it was possible to reduce the parasitic load of the animals by more than $60 \%$. These authors dedicated the hypoglycemic action result of the plant on the parasite since it uses glucose as an energy reserve for maintenance and the plant used would probably not make glucose and other nutrients available to the parasites present in the intestinal lumen. Similar results to this study were also verified by Aziz et al. (2018) when evaluating the anthelmintic efficacy of pomegranate peels on birds naturally infected with $A$. galli. The results described by these authors demonstrated action on the parasites in the concentrations of 25 and $50 \mathrm{mg} / \mathrm{ml}$ of ethanolic extract of the pomegranate peel when compared with the drug commonly used for treating worms in birds, and are also very similar results to those found in this study.

According to Oliveira et al. (2010), the active compounds of vegetables are being studied to control intestinal parasites because they have several secondary compounds responsible for not providing nutrients for their development; among them the authors highlight the tannins, which are the most commonly found secondary metabolites in plants and present in large quantities in pomegranate.

The inhibition rates on the development of Heterakoidea superfamily larvae by flor-de-seda extract in different concentrations can be seen in Table 2 .

Table 2. Averages of the results of the activity of the aqueous extract of silk flower, calculated through the rate of inhibition of the development of larvae in eggs of the Superfamily Heterakoidea in different concentrations

\begin{tabular}{|c|c|c|c|c|}
\hline \multirow[b]{2}{*}{ Treatment } & \multirow[b]{2}{*}{$\begin{array}{c}\text { Concentrations } \\
(\%)\end{array}$} & \multicolumn{3}{|c|}{ Larval Development Inibition (\%) } \\
\hline & & 24 hours & 48 hours & 72 hours \\
\hline \multirow{5}{*}{ Flor de seda } & 03.12 & $10.5 \mathrm{a}$ & $16.0 \mathrm{a}$ & $14.0 \mathrm{a}$ \\
\hline & 06.25 & $10.8 \mathrm{a}$ & $16.0 \mathrm{a}$ & $13.0 \mathrm{a}$ \\
\hline & 12.50 & $10.5 \mathrm{a}$ & $15.5 \mathrm{a}$ & $18.0 \mathrm{a}$ \\
\hline & 25.00 & $24.0 \mathrm{a}$ & $38.0 \mathrm{a}$ & $19.0 \mathrm{a}$ \\
\hline & 50.00 & $30.5 \mathrm{a}$ & $31.0 \mathrm{a}$ & $21.5 \mathrm{a}$ \\
\hline No treatment $*$ & - & $05.0 \mathrm{~b}$ & $12.0 \mathrm{~b}$ & $07.0 \mathrm{~b}$ \\
\hline Albendazole ** & 10 & $20.0 \mathrm{a}$ & $15.0 \mathrm{a}$ & $21.0 \mathrm{a}$ \\
\hline
\end{tabular}

* Negative control (-)

** Positive control $(+)$

Means followed in different letters by the Tukey test $(p<0,05)$ 
There was a significant effect when comparing the different concentrations of flor-de-seda aqueous extract with the negative control treatment, and not differing in either concentration with the treatment using the drug (Albendazole 10\%), although the concentrations of 25 and $50 \%$ in all analyzed periods (24 to 72 hours) showed superior larvae inhibition effect when compared with the positive control.

The most commonly identified active principles responsible for the anthelmintic activity of $C$. procera are: alkaloids, phenolic compounds and saponins; however, the action mechanisms involved have not been very well elucidated. The authors do describe the in vitro and in vivo spasmogenic effects of flor-de-seda latex on gastrointestinal smooth muscles (Kumar \& Shivkar, 2004) and the in vitro spasmolytic effect of $C$. procera extract on smooth musculature (Iwalewa et al. 2005).

When analyzing the effect of the two aqueous extracts, the pomegranate extract showed up to $78 \%$ efficacy for the concentration of $25 \%$, while the flor-de-seda extract in the concentration of up to $50 \%$ for the period of 72 hours showed similar activity to that of the drug used as a positive control (Albendazole 10\%), demonstrating the potential of these herbal extracts to inhibit development of Heterakoidea superfamily larvae.

The results of this study corroborate other studies by Grzybek et al. (2016) and Cordeiro et al. (2010) who studied the use of herbal extracts in treating gastrointestinal helminths of farm animals and therefore recommended herbal extracts as a viable alternative for replacing antiparasitic agents used in the market.

The pomegranate ( $P$. granatum) aqueous extract is effective in the "in vitro" treatment of gastrointestinal nematodes of Japanese quails (C. $c$. Japonica), with greater efficiency in concentrations at 25 and $50 \%$. The florde-seda aqueous extract (C. procera) was less efficient when compared to that of pomegranate for inhibiting the development of gastrointestinal nematode larvae in quails. In vivo studies are needed to validate the use of alternative natural substances for the control of parasites in Japanese quail farming.

\section{REFERENCES}

AZIZ, A.R.A.; LAILA, M.R.A.; AZIZ, M.; OMAR, M.A.; SULTAN, K. In vitro and in vivo anthelmintic activity of pumpkin seeds and pomegranate peels extracts against Ascaridia galli. Journal of Basic and Applied Sciences, v.7, n.2, p.231-234, 2018.

ABDELQADER, A.; QARALLAH, B.; AL-RAMANEH, D.; DAS, G.

Anthelmintic effects of citrus peels ethanolic extracts against Ascaridia galli. Veterinary Parasitology, v.188, p.78-84, 2012.

ABDEL MONEIM, A. E. Evaluating the potential role of pomegranate peel in aluminum-induced oxidative stress and histopathological alterations in brain of female rats. Biological Trace Element Research, v.150, p.328-336, 2012. 
ARAÚJO, M. M.; VILELA, V.L.R.; SILVA, W.A.; SOUSA, R.V.R.; FEITOSA, T.F.; ATHAYDE, A.C.R. Eficácia anti-helmintica in vitro do extrato etanólico de Operculina hamiltonii (g. Don) d.f. austin \& staples (1983) - batata de purga. ARS

Veterinária, v.27, n.3, p.192-196, 2011.

CORDEIRO, L.N; ATHAYDE, A. C. R.; VILELA, V.L.R.; COSTA, J.G.N.; ARAÚJO, M.M.; RODRIGUES, O.G. Efeito in vitro do extrato etanólico das folhas do melão-de-São-Caetano (Momordicacharantia L.) sobre ovos e larvas de nematoides gastrintestinais de caprinos. Revista Brasileira de Plantas Medicinais, v.12, n.4, p.421-426, 2010.

CAVALCANTE, G. S.; MORAIS, S. M.; ANDRE, W. P. P.; RIBEIRO, W. L. C.; RODRIGUES, A. L. M.; DE LIRA, F. C. M. L.; VIANA, J. M.; BEVILAQUA, C. M. L. Chemical composition and in vitro activity of Calotropis procera (Ait.) latex on Haemonchus contortus. Veterinary Parasitology, v.226, p.22-25, 2016.

CARNEIRO M.B.; CALAIS JÚNIOR, A.; MARTINS, I.V.F. Avaliação coproparacitológica e clínica de aves silvestres e exóticas mantidas em criatórios particulares no município de Alegre/ES. Ciência Animal Brasileira, v.12, n.3, p.525- 529, 2011.

COLES, G.C.; BAUER, C.; BORGSTEEDE, F.H.M.; GEERTS, S.; KLEI, T.R.; TAYLOR, M.A.; WALLER, P.J. World Association for the advancement of Veterinary Parasitology (W.A.A.V.P.) methods for detection of anthelmintic resistance in nematodes of veterinary importance. Veterinary Parasitology, v.44, p.3544, 1992.

DKHIL, M. A. Anti-coccidial, anthelmintic and antioxidant activities of pomegranate (Punica granatum) peel extract. Veterinary Parasitology, v.112, p.2639-2646, 2013.

FERNANDES, M. Z. C. M.; FERNANDES, R.M.; BRITO, D.R.B.; BORBA, H.R. Efeito anti-helmíntico dos extratos aquosos e etanólicos da Annona squamosa L. (fruta-do-conde) sobre o nematóide Ascaridia galli.

Revista Brasileira de Plantas

Medicinais, v.11, n.2, p.124-129, 2009.

FEITOSA, T. F.; VILELA, V.L.R.; ATHAYDE, A.R.; BRAGA, F.R.; DANTAS, E.S.; VIERIA, V.D.; MELO, L.R.B. Anthelmintic efficacy of pumpkin seed (Cucurbita pepo Linnaeus, 1753) on ostrich gastrointestinal nematodes in a semiarid region of Paraíba State, Brazil. Tropical Animal Health Production, v.45, p.123-127, 2013.

GRZYBEK, M.; KUKULA-KOCH, W.; STRACHECKA, A.; JAWORSKA, A.; PHIRI, A.M; PALEOLOG, J.; TOMCZUK, K. Evaluation of Anthelmintic Activity and Composition of Pumpkin (Cucurbita pepo L.) Seed Extracts-In Vitro and in Vivo Studies. International Journal of Molecular Sciences, v.17, n.1, p.E1416, 2016.

GIRÃO, E.; UENO, H. Técnica de quatro tamises para o diagnóstico coprológico quantitativo da fasciolose dos ruminantes. Pesquisa 
Agropecuária Brasileira, v.20, n.8, p.905-912, 1985.

HUBERT, J.; KERBOEUF, D.A new method for culture of lavae used in diagnosis of ruminant gastrointestinal Strongylosis: comparison with fecal cultures. Canadian Journal of Comparative Medicine, v.48, n.1, p.63-71, 1984.

IWALEWA, E.O., ELUJOBA, A.A., BANKOLE, O.A. In vitro spasmolytic effect of aqueous extract of calotropis procera on guinea-pig trachea smooth muscle chain. Fitoterapia, v.76, p.250-253, 2005.

KUMAR, V.L., SHIVKAR, Y.M. In vivo and in vitro effect of latex of Calotropis procera on gastrointestinal smooth muscles. Journal of Ethnopharmacology, v.93, p.377-379, 2004.

NERY, P.S.; DUARTE, E.R.; MARTINS, E.R. Eficácia de plantas para o controle de nematóides gastrintestinais de pequenos ruminantes: revisão de estudos publicados. Revista Brasileira de Plantas Medicinais, v.11, n.3, p.330-338, 2009.

OLIVEIRA, L.P.; PINHEIRO, R.C.; VIEIRA, M.S.; PAULA, J.R.; BARA, M.T.F.; VALADARES, M.C. Atividade citotóxica e antiangiogênica de Punica granatum L., Punicaceae. Brazilian Journal of Pharmacognosy, v.20, p.201207, 2010.

RUFF, M. D. Important parasites in poutry production systems.Veterinary parasitology, v. 84, p. 337-347, 1999.

SILVA, A.F.; SGAVIOLI, S.; DOMINGUES, C.H.F.; GARCIA, R.G. Coturnicultura como alternativa para o pequeno produtor rural. Arquivo Brasileiro de Medicina Veterinária e Zootecnia, v.70, n.3, p.913-920, 2018.

SABRI, M.H. Comparison the effeciancy of levamisole and dry Punica granatum peel against Ascaridia galli in layer hens that naturally infested.

Euphrates Journal of Agriculture Science, v.5, n.3, p.1-13, 2013.

TARIQ, K. A.; TANTRY, M. A. Preliminary Studies on Plants with Anthelmintic Properties in Kashmir-The North-West Temperate Himalayan Region of India. Chinese Medicine, v.3, p.106-112, 2012.

VITA, G.F.; FERREIRA, I.; PEREIRA, M.A.V.C; SANAVRIA, A.;

AURNHEIMER, R.C.M.; BARBOSA, C.G.; GALLO, S.S.M.;

VASCONCELLOS, H.V.G. Eficácia de Chenopodium ambrosioides (erva-desanta-maria) no controle de endoparasitos de Coturnix japonica (codorna japonesa). Pesquisa Veterinária Brasileira, v.35, n.5, p.424-435, 2015.

VITTA, G. F.; FERREIRA, I.; PEREIRA, M.A.V.C.; AZEVEDO, J.R.; SANAVRIA, A.; BARBOSA, C.G.; GALLO, S.S.M.; VASCONCELLOS, H.V.G. Eficácia de Chenopodium ambrosioides (erva-desanta-maria) no controle de endoparasitos de Gallus gallus (galinha caipira). Pesquisa Veterinária

Brasileira, v.34, n.1, p.39-45, 2014.

ZAR, J. H. 1999. Biostatistical analysis. Prentice Hall. Upper Saddle River. New Jersey. 663 pp. 